\title{
INTERNATIONAL ACQUISITIONS FROM A NETWORK PERSPECTIVE AND MARKET BASED COMPETENCIES
}

\author{
Timothy S. Kiessling \\ Eastern Kentucky University \\ Richmond, KY \\ R. Glenn Richey \\ The University of Alabama \\ Tuscaloosa, AL
}

\begin{abstract}
Trillions of dollars are spent annually on international acquisitions and often these acquisitions are considered a failure in regard to performance. The importance of valuation of an international target firm cannot be underestimated. especially in the global market where networks of strategic alliances are required to compete. For international acquisitions - the value of the firm is often its network of relationships. Thus, the valuation by the acquiring firm takes on new - more complex - dimensions than simply reviewing the Balance Sheet and Income Statement results. This manuscript explores the valuation of international target acquisitions when the intangible value is its network of strategic alliances. Additionally, the manuscript employs theory and grounded examples to develop a theoretical model for future examination.
\end{abstract}

\section{Introduction}

The market for international expansion is certainly a complex one for managers to navigate. The complexity is increasing as domestic markets continue to become more concentrated, economic barriers to trade continue to fall, transportation and technological advances lower physical barriers to trade, and international trade blocks continue to form. Yet each of these complexities can also be considered a motivation as, now more than ever, firms are encouraged to enter the global marketplace. One popular choice of international market entry, international acquisition, continues to be a course taken by many firms.

In 1984 , in the United States alone, nearly $\$ 36$ billion was spent in acquiring 241 firms. In 1998 it was estimated that over $\$ 1$ trillion was spent in international acquisition activity (Business Week, 1998). In 1999, in the United States alone, $\$ 1.75$ trillion in mergers and acquisitions were announced and $\$ 3.4$ trillion was spent worldwide (Hitt, Harrison and Ireland, 2001). Recent examples of this strategy are Petro-Canada's $\$ 3.2$ billion acquisition of Verba Oil and Gas GMbH (January, 02), China National Off Shore Oil Co.'s $\$ 598$ million purchase of Rep- 
sol-Yepeo (December, 01), Tyco International's $\$ 650$ million purchase of Paragon trade brands (December, 0 I), and Baxter International's $\$ 470$ million purchase of Asta Medica Onkologie GMbH \& Co Kg (SEC filings, 2001, 2002).

In 2002 , over 5,400 deals worth more than $\$ 346$ billion were announced through September 30 (Business Week, 2002). The managerial importance of the international acquisition phenomena is made apparent by the size of these figures alone. Subsequently, expansion through acquisition continues to be a viable international strategy utilized by firms. As these numbers grow - so grows the importance of the correct valuations of a target firm. Managers will no doubt be forced to access both the traditionally tangible assets and the often more important intangible market based assets to arrive at an appropriate valuation of an international acquisition.

Increasingly the question becomes how to value potential international acquisitions. Numerous answers, that are often conflicting, have been proposed. Most of these focus on valuation with disregard to one of the true values of the target firm: its network of relationships. This manuscript suggests the potential value of a target firm's intangible assets (such as the firm's network or relationships) is much greater than the value of the tangible assets (Lusch, Harvey, and Speier, 1998). Specifically, this manuscript focuses on the determinants of value of an acquisition when its value is its network.

Researchers have investigated the logic behind the acquisition/ownership decision for years. The Transaction Cost Theory (Williamson, 1975) rationale for acquisition rests with minimizing the sum of production and transaction costs. The Resource-Based View (Wernerfelt, 1984) suggests that through acquisition a firm can maximize value by gaining access to the target firm's valuable resources (Madhok, 1997; Ramanathan, et. al., 1997). Additionally, the Resource-Based View suggests that, as a firm acquires another firm for its network of relationships, it must be able to utilize the very same network it is hoping to acquire to earn normal returns (Wernerfelt, 1984). It is definitely an unrealistic assumption to expect that the entire network of relationships will transfer to the acquiring firm. Issues such as network or partner incompatibility, cultural distance, loss of boundary spanners, insufficient resources of the acquirer, and/or positional embeddedness within the network may all deter ongoing relationships between the acquirer and the established network. If the acquisition is driven by the intangible value of the target firm's network of relationships, it must be recognized that any loss of network partners may devalue the target firm.

The focus of this manuscript is on how to value the acquisition of an international foreign target firm when its value is its network of relationships. Strategic theories of management and marketing that make up the Network Paradigm - Transaction Cost Theory, the Resources Based View, and Relationship Marketing - will be used to determine the relative value of the integration of the acquirer into the target firm's network. First, we will review the literature in regard to networks and then apply the literature to international valuation of firm acquisition. Next, we will develop propositions that derive a model of the valuation of international 
firms from a network perspective. Finally, we will discuss the implications of the model and draw conclusions.

\section{The Network and Firm Value}

The global economy has created a new competitive landscape - one in which events change constantly and unpredictably (Ireland and Hitt, 1997). Even before the forces of global competition became more visible, there was a trend toward more flexible organizations. These organizational forms are difficult to capture with a traditional organization chart because they include a network of complex relationships that provide value to the firm as a whole (Miles and Snow, 1984, 1986; Powell, 1990; Thorelli, 1986; Webster, 1992). This shift in organizational form drives the research focus away from transactions and towards relationships. Here, customers become partners and the firm must make long-term commitments to maintaining quality, service, and innovation (Anderson and Narus, 1991). Instead of developing these relationships over time some firms hope that the acquisition of a target firm will automatically transfer the existing network of relationships. Thus, the inherent value placed upon a network of relationships is contingent upon its transferability.

To compete effectively in the global dynamic economy firms have evolved to focus on large-scale managed networks representing a legitimate alternative to markets or hierarchy. Embeddedness (concrete relations and structures "networks" which generate trust and discourage malfeasance) is the fundamental concept differentiating the Network Paradigm from economic theories of organization (Granovetter 1985).

A firm's core competency may be the valuable resource and capabilities that attract acquisition attempts. Specific to each successful company is a core competency, or a unique amalgam of skills, resources, technologies, people, etc, that make a company a leader in a specific area (Valentino, 1992; Planning Review, 1994). Core competencies are described as unique, not imitable by competitors, and sustainable or durable (lasting). These core competencies are frequently composed of intangible assets that allow a company to effectively compete in marketplaces and to differentiate themselves from primary competitors (Willens, 1993; Prahalad and Hamel, 1990). Examples of intangible assets are: 1) company reputation, 2) product reputation, 3) employee know-how, 4) networks, 5) supplier know-how, 6) databases, and 7) distribution know-how (Hall 1992). If the core competency of the international target firm is its network of relationships, supplier know-how, or distributor know-how (Hall's, 1992; 1993) the question then becomes how to value the target firm.

Financial analyses frequently fail to recognize that the acquisition includes an important network of firm and human relationships, as well as, financial activity. In focusing only on financial results - such as income statement, ratios, and balance sheet issues - the role of people, knowledge gained, and/or other immeasurable goals are often overlooked (Hunt, 1987; Levinson, 1970; Kitching, 
1967). Despite this, acquisition decisions and negotiations still typically center on financial results and rarely involve any analysis of relationships (Cartwright and Cooper, 1992). For example, a recent study illustrates that although all the organizations in the study conducted detailed and thorough legal and financial audits, no audit in regard to human resources occurred. Surprisingly, thirty percent considered the implications of a pension plan which is directly related to retention of employees and thus intangible relationships (Hunt, 1987).

In an international acquisition, the managers of the acquirer firm must be cautious in evaluating the target's value based solely on accounting measures. This is because managers at the target firm have discretion as to what accounting methods and allocation procedures (ex. overhead, indirect costs, etc.) will be utilized. Thus, target managers may intentionally or unintentionally inflate the costs/value of the acquisition. Accounting practices can significantly impact such things as the setting-up of accruals, writing off goodwill, eliminating costs from other divisions through allocation, etc. Possibly the largest flaw in utilizing accounting measures, especially in the new knowledge economy, is the valuation of intangible assets and liabilities. A firm's intangible resources and capabilities are productive assets that are difficult to observe, describe, and value. Nevertheless, these resources can have a significant impact of a firm's performance. Researchers have noted that the impact of this limitation is great and the magnitude for misrepresentation is significant (Fisher and McGowen, 1983; Ijiri and Kelly, 1980).

Recent research has focused on the external value of the firm or firm's market based asset value. Market based assets fall into two categories: 1) relational - outcomes of the relationship between a firm and key external stakeholders, including distributors, retailers, end customers, other strategic partners, etc.; and 2 ) intellectual - the types of knowledge a firm possess about the environment, such as the emerging and potential state of market conditions and the entities in it (Srivastava, et. al., 1998). The most common market based assets include: brand equity (Aaker, 1991; Keller, 1993; Shocker, Srivastava, and Ruekert, 1994), customer satisfaction (Yi, 1990) and the management of strategic relationships (Anderson and Narus, 1996; Bucklin and Sengupta, 1993).

Traditional theories describing marketing channel interactions are founded on the assumption that in the absence of suitable safeguards, economic agents are prone to opportunistic and self-interest-seeking behavior (Williamson 1975). Thus, firms must determine the most efficient contract to govern the relationship given the characteristics of the parties involved. Still, the fact remains that environmental uncertainty and the costs of obtaining information make it impossible for the principle to efficiently and effectively monitor the agent completely (Agency Theory, Arrow 1985). Thus, network theories have evolved to explain phenomena that emphasize the normative and social structure in which exchanges are embedded as the primary determinant of behavior (Granovetter, 1985).

Much of the research in relationship management and marketing strategy point to the mediating and moderating characteristics of key relational variables. Such 
is the case with firm trust and commitment (Morgan and Hunt 1994); interpersonal relationships (Crosby, Evans, and Cowles 1990); and relational aspects of culture (Nakata and Sivakumar 2001). A central theme in these works is the importance of relationships to the success of the firm. Thus, the value of a firm may often be attributed to its network of relationships.

\section{Positional Embeddedness of Firm and Acquisition Valuation}

Positional embeddedness of a firm captures the impact of the positions organizations occupy in the overall structure of the alliance network. The more central an organization's network position, the more likely it is to have better information about a larger pool of potential partners in the network (Gulati and Gargiulo, 1999). The embeddedness argument stresses the role of concrete personal relations and structures (or networks) of such relationships in generating trust and discouraging malfeasance (Granovetter, 1985).

The greater the centrality of the positional embeddedness of a firm, the more valuable the firm should be (Gulati and Gargiulo, 1999). Hence, the control of information throughout the network should create valuable opportunities for the central firm, as well as its more numerous contacts. It is the central firm that often decides whether to allow new firms to enter the fringes or to end relationships with those found untrustworthy or invaluable.

Communication is a capability used to coordinate outputs. Communication serves to embed an organization in its environment and network. Guetzkow (1965) identifies several important characteristics of communication in organizations, including formal and informal flows; vertical and lateral flows; and omissions and distortions. Ultimately, "...communication can be described as the glue that holds together a channel of distribution (Mohr and Nevin, 1990, p. 38)."

The positional embeddedness of a firm in an international marketplace is of great value to an acquirer who may know little of the host-country marketplace. The information flow from the network members may assist the acquirer in entering the new marketplace and allow for some early control over other network members.

\section{Grounded Evidence Part One}

On September 23, 2002, DATATRAK International (Ohio) announced a definitive agreement to acquire French technology firm Oriam. Dr. Jeffrey A. Green, President \& Chief Executive Officer of DATATRAK International, Inc., suggests that the acquisition was very much in regard to Oriam's central role in its network (i.e. Oriam's customer base and knowledge base). Oriam's customer base currently includes 33 clients, predominantly European-based pharmaceutical companies, although expansion into the American markets was recently evident with the adoption of Oriam's software suite by a prominent biotechnology firm and a major U.S. academic medical center. Several of Oriam's key customers 
have utilized its technology for many years and have progressively expanded their base to more than 500 users per company.

"This strategy is based on management's conviction that the breadth of technological applications used in clinical trials should be integrated and follows a continuous [continuum], compatible, and progressive flow of information... However, in today's environment for clinical trials such integration is presently absent. At this time, there only exist 'point solutions' throughout this industry offered by a variety of different companies with completely disjointed data models - none of which inherently or easily communicate with each other" (PR Newswire Europe, 2002). In essence, Oriam's central control of their client's technology and reporting structures is the value focus of this acquisition. Therefore, we propose:

Position 1: The international decision-maker's valuation of a target acquisition will be higher when he/she perceives high centralization of the target firm within a network.

\section{Dependence and Network Compatibility to Acquisition Valuation}

\section{Dependence and Acquisition Valuation}

Dependence is generally described as: Firm A's dependence on B is directly proportional to the motivational investment in goals mediated by $\mathrm{B}$ and inversely proportional to the availability of those goals to A outside the A-B relationship (Emerson, 1962). Pfeffer and Salancik (1978) argue that dependence comprises three elements: 1) the importance of the resource and the extent to which the organization requires it, 2) the extent to which the other party has discretion over that resource, and 3 ) the extent to which there are few alternatives.

For example, a firm is considered more dependent on a supplier when that supplier provides a larger fraction of its business. If alternative suppliers are not available (i.e. options are limited), dependence also exists. Transaction Cost Theory also postulates that transaction specific investments (assets of considerable cost with few to no alternative uses) may create a dependency situation (Williamson, 1985). Identification of large asset specific holdings by network partners may result in "hostage" type relationships by the acquiring firm until and only if other relational options can be established.

Resource dependence theory suggests that a lack of self-sufficiency creates potential dependence on the parties from whom the focal resources are obtained (Emerson, 1962). The main implication is its identification of dependence and uncertainty as the key antecedent variables motivating the establishment of interfirm relationships. As the acquisition occurs, firms may re-evaluate their relationship with the acquirer, especially when the acquirer is of a different nationality.

Management practices and routines vary significantly due to differences in national culture (Hofstede, 1983). Thus cultural uncertainty may increase for the acquiring firm (in the target firm's network) after acquisition. However, if the 
network of firms is resource dependent upon the target firm, they may not immediately embark on the uncertain territory of establishing new ties. The greater the uncertainty of other firms within the market, the greater the potential that the acquirer may be given the opportunity to establish a relationship within the network. With an inability to obtain focal resources, the network may continue to rely on the acquirer unless negative market signals are delivered.

\section{Network Compatibility and Acquisition Valuation}

If an acquisition attempt is to have an opportunity to have access to the network relationships the target firm has, one must realize that in an international/cross cultural context the network may be culturally directed (such as in a Kieretsu or Chaebol). Moreover, the acquiring firm brings its own network of strategic alliances and relationships into the scenario. In this ambiguous and complex configuration of firms that constitute the network, the firm themselves develop network identities (Hakansson and Johanson, 1993). Network identity is meant to capture the perceived attractiveness (or repulsiveness) of a firm to an exchange partner due its unique set of connected relations with other firms, links to their activities, and ties with their resources (Anderson, Hakansson, and Johanson, 1994). Each identity communicates a certain orientation toward other actors.

The identity of the acquiring firm may be deemed unacceptable/unsuitable to the members of the network due to past performance, the relationships it has established in its network of suppliers or customers, a nationalistic network (ex. Chaebol), or even direct competition with the new network members. Thus, the network the acquiring firm is embedded in may actually hinder successful entry through acquisition. Gulati and Gargiulo (1999) show that membership in one cohesive network truly hinders the ability to build cooperative ties with other networks. Acquiring the target member of a network due to its value of network relationships does not represent an automatic "get in free card" for the acquiring firm. Acquirer network associations and those of the target firm should be reviewed before committing resources to the acquisition.

An important element in any business partnership is a common business understanding, mission identity, or network identity. This has also been termed organizational identity (Albert and Whetton, 1985) meaning "the theory organizational members have about who they are" (Barney and Wright, 1998: p. 103). However this identity is not stable and evolves as new members enter and exit (Gioia, Schutz and Corley, 2000). In essence, the target firm also influences the acquiring firm's network and relationships among the members.

Each firm's network identity communicates a certain orientation toward other actors. It conveys a certain competence, because it is based on each actor's perceived capability to perform certain actions and is based on the particular resources each actor possesses (Yamagashi, Gillmore, and Cook, 1988). Allowing firms to enter the alliance without attention to composition can lead to conflict among a firm's partners. This is enhanced as duplication of roles, tasks, and positions creates rivalry among the partners (Gomes-Casseres, 1994). Careful attention should 
be paid to not only the compatibility of the purchaser's network, but to what the effect will be of the inclusion of the target's identity into the purchaser's network.

\section{Grounded Evidence Part Two}

PLIVA's (Croatia) June 11, 2002 acquisition of US-Based Sidmak Laboratories for $\$ 219$ million was done mainly to access Sidmak's network. Zeljko Covic, Chief Executive Officer of PLIVA, suggested that direct access to the US pharmaceutical market through an established sales network, an experienced management team, and skilled employees were the main reasons for acquisition (Business Wire, 2002a). If PLIVA anticipated loss of either the sales network or the internal network, the target acquisition would either not have occurred or would have been valued at a lower price. Therefore in regard to dependence and network compatibility we propose:

\section{Position 2: The international decision-maker's valuation of a target acquisition will be higher when he/she perceives a higher level of dependence of and compatibility in the network to the target firm.}

\section{Network Based Relational Density and Acquisition Valuation}

In essence, what makes the network valuable is the quality of relationships. Relationship dimensions include: non-hierarchical/long-term commitments, multiple roles and responsibilities, mutuality, and affiliational sentiments. Therefore, what differentiates the network organization is its density, multiplexity, reciprocity of ties, and shared value system defining membership roles and responsibilities. In short network relationships add value to the firm (Achrol 1997).

\section{Grounded Evidence Part Three}

An example of such importance is the recent Daisytek International Corporation's (Texas) Aug. 19, 2002 acquisition of ISA International plc (UK), one of the largest pan-European distributors of computer supplies with revenues of more than $\$ 500$ million. Daisytek suggests that the synergistic combination of Daisytek's distribution expertise, financial resources, and management experience - combined with ISA's pan-European reach, customer relationships, and local knowledge may provide firm value (Business Wire, 2002b). The importance of the acquisition is in the network of customer relationships as well as local knowledge of the distribution, suppliers, and marketplace dynamics.

The number of functioning relationships a target holds in a network is a target's relational density. The relational density of a firm represents a significant contribution to the global success of the respective firm. The relationships between the target firm and alliance members may very well contribute extensively to the revenue generation and innovative ability of the firm. Transference of these 
relationships to the acquiring firm may, or may not, be accomplished. If the relationships do not transfer, performance may be negatively impacted. Additionally, the cultural distance of the firm may also directly affect the process of assimilation into relationship network. Therefore, we suggest:

Position 3: The international decision-maker's valuation of a target acquisition will be higher when he/she perceives higher relational density that will transfer with the acquiring firm.

\section{Credibility Portion of Trust and Boundary Spanner Retention to Acquisition Valuation}

\section{Transference of the Credibility Portion of Trust and Acquisition Valuation:}

Literature that is more recent examines networks from a Relationship Marketing perspective (Day, 1997). Relationship Marketing is seen as relationships, networks, and interactions in which two or more parties (supplier, customer, competitor, etc.) create value for each other. Relationship Marketing is part of the developing "network paradigm" which recognizes that global competition occurs increasingly between networks of firms (Thorelli, 1986). Frequently quoted properties of Relationship Marketing include trust, reliability, and commitment. Relationship Marketing is clearly more than a theory; it represents a paradigm shift in marketing thought (Gummesson, 1997).

Trust is dimensionalized as credibility (a partner's perception of require expertise to perform a job effectively) and benevolence (a partner's perception that the intentions and motives of the other firm, when reacting to new conditions, will match its needs) (Ganesan, 1994). Several terminologies are borrowed from Transaction Cost Theory including opportunistic behavior and transaction specific assets (Williamson, 1981). In Relationship Marketing, relational governance or relational contracting is seen as providing the best (both lowest cost and productive) governance mechanism and transaction specific investments may be shared due to high levels of trust.

A firm that that enters a network through the acquisition of another firm may not transfer the benevolence portion of trust that has been developed over time (i.e. history of actions/interactions). This may occur despite the acquiring firm having substantial credibility identified/signaled through its resources, its history of actions within it current network, and/or market capabilities. The acquiring firm may transfer the credibility portion of trust, but it may take time to successfully develop the benevolence portion if at all.

\section{Grounded Evidence Part Four}

Vincor International Inc., one of North America's largest producers of wine and related products announced on October 9, 2002 that it has entered into a definitive agreement to purchase privately held Goundrey Wines of Australia. "Goun- 
drey also has an excellent network of distributors and company sales force which provides an outstanding platform for continued sales growth within Australia," said Donald Triggs, Vincor's President and CEO. From the Goundrey side, "I am pleased that joining Vincor and leveraging its economies of scale and growing distribution reach may provide an opportunity for our exceptional people and wines to realize their full potential in domestic and international markets", added Jack Bendat, Goundrey's owner and Chairman. "Equally important to our decision to join Vincor was its ongoing commitment to preserve the unique culture and identity of each member of its growing family of estate wineries." (Canada News Wire Ltd., 2002).

\section{Boundary Spanner Retention and Acquisition Valuation}

A major source of information relevant for firms and networks is boundary spanners. Boundary spanning refers to the effective interaction between an organization and its external environment through people or firms. Boundary spanners link an organization to its environment by the nature of their interactions with non-members (Thompson, 1967). Boundary spanning communication is important to organizations as a source of new information that increases awareness of environmental changes (Weedman, 1992). Ultimately, boundary spanners facilitate an even flow of information between the two or more parties. This vital transference of information allows the parties to share strategic views on the external market environment, mutually decide a course of action, and then implement a truly synergistic strategy.

Dyer and Singh (1998) described knowledge sharing routines as a regular pattern of interfirm interactions that permits the transfer, recombination, or creation of specialized knowledge. Von Hippel (1978) argues that a production network with superior knowledge transfer mechanisms among users, suppliers, and manufacturers may be able to "out innovate" production networks with less effective knowledge sharing routines.

The cultural differences that an international acquisition may have to overcome to build upon a network of strategic alliances require the establishment and management of informal and formal communication chains. Boundary spanners help establish and manage these chains of communication that may assist in overcoming many of the cultural differences that threaten future relations. For example, personal relationships among key individuals have played a crucial role in producing trust between organizations in Japanese industrial groups (Lincoln, Gerlach, and Ahmadjian, 1996) and in contractual relationships (Bradach and Eccles, 1989). Beneath the formalities of contractual agreements, multiple formal interpersonal relationships emerge across organizational boundaries, which facilitate the active exchange of information and the production of trust that foster interorganizational cooperation (Walker, Kogut, and Shan, 1997; Gulati, 1995).

Culture diversity can be an obstacle in cross-national business relationship communication. Previous research has shown that developed country joint ventures tend to have an instability rate of around $30 \%$ with developing countries 
between $45 \%$ to $50 \%$ (Beamish, 1984; 1985; Reynolds, 1984). Although joint ventures have concerns that differ from acquisitions, the failure rate due to cultural diversity is a point not to be over looked.

\section{Grounded Evidence Part Five}

The Daimler-Benz acquisition of Chrysler corporation appeared to be a sure success due to the potentially complementary core businesses of the two firms; that of Chrysler's mid-priced autos and minivans and Daimler's luxury automobiles. However, due to major difficulties in cultural nuances and complicated communication, integration was difficult and performance of the merged firm suffered. Even worse, many members of Chrysler quit, and with them their network of relationships was lost. In addition, Wal-Mart acquired a 21 -store hypermarket in 1997 and acquired 74 Interspar stores in 1998. They imposed their own style of management and suffered significant human resource loses (turnover) due to cultural problems. Wal-Mart learned from this experience when it approached target firms in England. It gave the managers the freedom to adjust market style to fit the necessary cultural nuances and be successful (Zellner, et. al., 2001). Given this extended discussion on the transference of the credibility portion of trust and boundary spanner retention, we propose three possible moderating relationships:

Position 4a: The international decision-maker's valuation of a target acquisition will be higher when he/she perceives high centralization of the target firm within a network given the retention of the target firm's existing relationships.

Position 4b: The international decision-maker's valuation of a target acquisition will be higher when he/she perceives a higher level of dependence of and compatibility in the network to the target firm given the retention of the target firm's existing relationships.

Position 4c: The international decision-maker's valuation of a target acquisition will be higher when he/she perceives higher relational density that will transfer with the acquiring firm given the retention of the target firm's existing relationships.

\section{Summary and Managerial Implications}

The dynamic global marketplace has forced firms to utilize networks of relationships and strategic alliances as a vehicle for international success. As firms expand internationally, the acquisition of firms continues to be a popular mode of market entry. To value these international target firms, acquiring firms use tangible assets and intangible assets as tools. Often the true value of a firm is the 
intangible value of its network of strategic alliances. Due to the network as the source of value of the acquisition target, the importance of the acquiring firm's ability to maintain these relationships is examined.

We have discussed the value of the target firm due to its network of relationships from a theoretical perspective. This was accomplished through the examination of several components of the Network Paradigm including: Transaction Cost Economics, the Resource Based View, and Relationship Marketing. A managerial holistic model of international target firm valuation follows (see Figure 1).

\section{Figure 1}

\section{A Valuation Model of International Acquisitions}

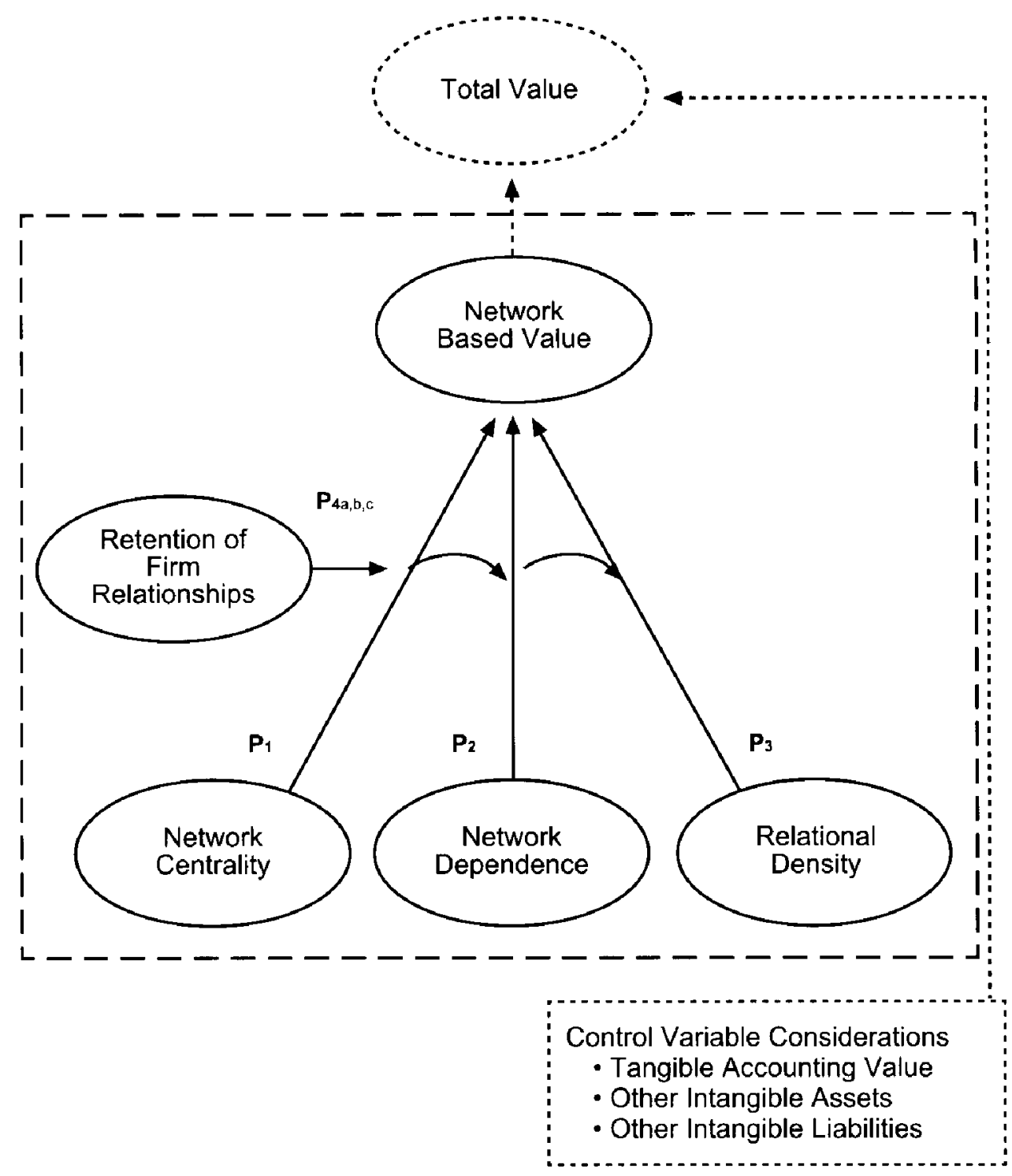


The acquisition target's value is due to its network of relationships developed over time. The acquiring firm may value the target corresponding to the number of relationships. The greater the number of relationships, the larger the network and ability to obtain new sources of competencies from other firms, thus making the target firm more valuable. Unfortunately, a firm can be overvalued if the relationships cannot be transferred to the acquiring firm. Major local suppliers, customers, etc., or groups of these relationships, if perceived to potentially be lost, may then force decision-makers to lower the projected value of the target and/or cancel the acquisition.

Firms are either developing or entering networks to compete in the global market. These networks each have an identity of their own and the firms within identify themselves as such. The acquisition of a firm due to its value within a network also suggests that this firm has a network identity that may or may not be compatible with the acquiring firm's network. If the networks are incompatible, the perceived resulting value may diminish due to the inability to transfer the relationships. As noted, although a greater number of relationships makes more resources available, the inability to transfer a larger number of these, especially key relationships, would diminish the value of a target firm.

The target firm may be valued higher when the network has a high dependency on it and if the firm is centralized within the network. Dependence of other firms on the target firm may give the acquiring firm time to begin to establish a relationship. If the acquirer's resources and reputation are credible, this portion of trust could transfer and hopefully develop the benevolence portion of trust over time. The centralization of the target firm within the network makes the firm more valuable as it controls most of the information and often decides which firms will enter/exit the network. This control of knowledge also creates increased network dependence on the target firm.

In essence, international acquisition managers must evaluate their own firm's resources, reputation and network with regard to the target firm. If the networks are not compatible or their resources and reputation are not transferable, the target firm's valuation may decline. If the target firm has high dependence on other firms (or interdependence within the network) and is central within in its network, then the acquiring firm may value the firm more highly. If the relationships within the network appear to not transfer and the boundary spanners appear not willing to remain and assist with the acquisition transition, then the target firm may be devalued. Of course, there are combinations and many of the variables mitigate and moderate one another, but when the international strategy is acquisition due to a target firm's network, these variables must be inspected for proper valuation. 


\section{References}

Aaker, D. (1991). Managing brand equity. New York: The Free Press.

Achrol, R. (1991). Evolution of the marketing organization: New forms for dynamic environments. Journal of Marketing, 55(Oct.), 77-93.

Achrol, RS. (1997). Changes in the theory of interorganizational relations in marketing: Toward a network paradigm. Academy of Marketing Science. 25 (1): 56-72.

Albert, S. \& Whetton, D. (1985). Organizational identity". In L. L. Cummings and Barry Staw (Eds.) Research in organizational behavior, 7. (pp. 263-295). Greenwich, CT: JAI,

Anderson, E. \& Weitz, B. (1992). The use of pledges to build and sustain commitment in distribution channels. Journal of Marketing Research, 29 (Feb), 18-34.

Anderson, J. \& J. Narus (1991). Marketing as a focused market strategy, California Management Review, 33, 95-113.

Anderson, J. \& J. Narus (1996). Rethinking distribution: Adaptive channels. Harvard Business Review, 74, 112-122.

Anderson, J., Hakansson, H. \& Johanson, J. (1994). Dyadic business relationships within a business network context. Journal of Marketing. 58(10). 1-15.

Arrow, K. (1985) "The Economics of agency", In John W. Pratt and Richard J. Zeckhauser (eds.) Principles and agents: The structure of business (pp. 37-51)_Harvard Business School press, Boston, MA.

Axelrod, R. (1984). The evolution of cooperation. New York: Basic Books.

Barney, J. \& Wright, P. (1998). On becoming a strategic partner: The role of human resources in gaining competitive advantage. Human Resource Management. 37(1), 31-47.

Beamish, P. (1984). Joint venture performance in developing countries. Unpublished dissertation, University of Western Ontario.

Beamish, P. (1985). The characteristics of joint ventures in developing countries. Colombian Journal of World Business. 20, 13-19.

Blankenburg-Holm, Desiree, Eriksson, K., \& Johanson, J. (1999). Creating value through mutual commitment to business network relationships. Strategic Management Journal. 20, 467-486.

Bradach, J. \& Eccles, R. (1989). Price, authority, and trust: From ideal types to plural forms. Annual Review of Sociology.15,97-107. 
Bucklin, L. P \& Sengupta S. (1993). Organizing successful company marketing alliances. Journal of Marketing. 57, 32-46.

Business Week. (1998). That was just a warm-up, (12-28-98), p 151.

Business Week. (2002). Why most big deals don't pay off. (October 14).

Business Wire. (2002a). PLIVA announces acquisition of US-based Sidmak, (June 11).

Business Wire. (2002b). Daisytek announces proposed offer to buy ISA International plc, (May 7).

Canada NewsWire Ltd. (2002). Vincor International announces agreement to acquire Australia's Goundrey Wines October 9.

Cartwright, S. \& Cooper, C. (1992). Mergers and acquisitions: The human factor. Oxford, Butterworth-Heinemann.

Crosby, Lawrence A., Evans, K. R. \& Cowles, D (1990). Relationship quality in services selling: An interpersonal influence perspective. Journal of Marketing. 54 (July), 6881 .

D'Aveni, T. (1994). Hypercompetition: Manning the dynamics of strategic maneuvering. New York: The Free Press.

Day, G. (1994). The capabilities of market driven organizations. Journal of Marketing. $\underline{58}($ Oct), $37-52$.

Day, G. (1997). Maintaining the competitive edge: creating and sustaining competitive advantage in dynamic competitive environments. In G. Day and Reibstein (eds.) Wharton on dynamic competition. (pp. 48-75) New York: John Wiley.

Day, G. (2000). Managing market relationships. Academy of Marketing Science. 28, 2430.

Deschpande, R., Farley, J.V. \& Webster, F.E. (1993). Corporate Culture, Customer Orientation, and Innovativeness in Japanese Firms: A Quadrad Analysis. Journal of Marketing, $57,23-37$.

Doney, P., Cannon, J. \& Mullen, M. (1998). Understanding the influence of national culture on the development of trust. Academy of Management Review, 23(3), 601-620.

Drucker, Peter F., (1993). The ecological vision. New Brunswick, NJ, Transaction Publishers.

Dwyer, F., Schurr, P, \& Oh, S. (1987). Developing buyer-seller relationships. Journal of Marketing, 51 (April), 11-27. 
Dyer, J. \& Singh, H. (1998). The relationship view: Cooperative strategy and sources of interorganizational competitive advantage. Academy of Management Review. 23(4), $660-679$.

Emerson, R. (1962). Power-Dependence relations. American Sociological Review. 27(1), 31-41.

Emerson, R. (1981). Social exchange theory. In M. Rosenberg and R. Turner [Eds.]. Social psychology: Sociological perspective. New York: Basic Books.

Fisher, F. \& McGowan, J. (1983). On the misuse of accounting rates of return to infer monopoly profits. The American Economic Review, 73(1): 82-98.

Francis, N. P. (1991). When in Rome? The effects of cultural adaptation on intercultural Business Negotiations. Journal of International Business Studies, 22(3), 403-428.

Ganesan, S. (1994). Determinants of long-term orientation in buyer-seller relationships. Journal of Marketing, 58(2), 1-20.

Gioia, D.A., Schultz, M. \& Corley, K. G. (2000). Organizational identity image and adaptive instability. Academy of Management Review, 25(1): 63-92.

Gittell, J.H. (2002). Coordinating mechanisms in care provider groups: Relational coordination as a mediator and input uncertainty as a moderator of performance effects. Management Science, 48(11), $1408-1426$.

Gomes-Casseres, B. (1994). Group versus group: How alliance networks compete. Harvard Business Review. 72(4), 62-71.

Granovetter, M. (1985). Economic action and social structure: The problem embeddedness. American Journal of Sociology, 91 (November), 481-510.

Guetzkow, H. (1965). Communications in organizations, in Handbook of Organizations. J. March Ed. Chicago: Rand McNally and Company, 534-73.

Gulati, R. (1995). Social structure and alliance formation pattern: A longitudinal analysis. Administrative Science Quarterly, 40, 619-52.

Gulati, R. \& Gargiulo, M. (1999). Where do interorganizational network's come from? The American Journal of Sociology, 104(5), pp 1489-1502.

Gummesson, E. (1997). Relationship marketing as a paradigm shift, some conclusions from the 30r approach. Management Decision, 35(4), 267-272.

Hakansson, H. \& Johanson, J. (1993). Industrial functions of business relationships. Advances in International Marketing, 5, 13-30. 
Hall, R. (1992). The strategic analysis of intangible resources. Strategic Management Journal, 13, 135-144.

Hall, R. (1993) A framework linking intangible resources and capabilities to sustained competitive advantage. Strategic Management Journal, 14(8): 607-618.

Hitt, M.A., Harrison, J. S. \& Ireland, R. D. (2001). Mergers and acquisitions. New York: Oxford University Press

Hofstede, G., (1980). Culture's consequences. Beverly Hills, Ca: Sage.

Hofstede, G. (1983). The cultural relativity of organizational practices and theories. Journal of International Business Studies, 13, 75-89.

Hunt, J. (1987). Hidden extras-how people get overlooked in takeovers. Personnel Management, July: 24-26.

Ireland, R. \& Hitt, M. (1997). Performance strategies for high growth entrepreneurial firms. Frontiers of Entrepreneurship Research, 91-104.

Ijiri, Y. \& Kelly, E. C. (1980). Multidimensional accounting and distributed databases: their implications for organizations and society. Accounting, organizations and society. $\underline{5}(1): 115-122$.

Keller, K. (1993). Conceptualizing, measuring, and managing customer based broad equity. Journal of Marketing, 57, 1-22.

Kitching, J. (1967). Why do mergers miscarry? Harvard Business Review, November/ December: $35-42$.

Kohli, A. \& Jaworski, B, (1990). Market orientation, The construct, research propositions and managerial implications. Journal of Marketing, 54, 1-18.

Levinson, H. (1970). A psychologist diagnoses merger failures, Harvard Business Review, March-April: 84-101.

Lincoln, J., Gerlach, M. \& Ahmadjian, C. (1996). Keiretsu networks and corporate performance in Japan. American Sociological Review, 61(1), 67-87.

Luo, Y. (2001). Antecedents and consequences of personal attachment in cross-cultural cooperative ventures. Administrative Science Quarterly, 46(2), $177-201$.

Lusch, R. F., Harvey, M., \& Speier, C. (1998). ROl ${ }^{3}$, the building blocks for successful global organizations in the 21 rst century. European Management Journal, 16(6), 714-728.

Madhok, A. (1997). Cost, value and foreign market entry mode, The transaction and the firm. Strategic Management Journal, 18, 39-61. 
Marcus, A. (1988). Implementing externally induced innovations, a comparison of rule bound and autonomous approaches. Academy of Management Journal, 31, 235-256.

McNamara, C. P. (1972). The present status of the marketing concept. Journal of Marketing, 36, 50-57.

Miles, R. \& Snow, C. (1984). Fit, failure and the hall of fame. California Management Review, 26, 10-28.

Miles, R. \& Snow, C. (1986). Network organizations, new concepts for new forms. California Management Review, 28, 62-73.

Mohr, J. \& Nevin, J. (1990). Communication strategies in marketing channels: a theoretical perspective Journal of Marketing, 54(4): 36-52.

Morgan, R. \& Hunt, S. (1994).The commitment-trust theory of relationship marketing. Journal of Marketing, 58 (July), 20-38.

Nakata, C. \& Sivakumar, K. (2001). Instituting the marketing concept in a multinational setting, the role of national culture. Journal of the Academy of Marketing Science, $\underline{29}(3), 255-275$.

Norman, R. \& Ramirez, R. (1993). From value chain to value constellation, Designing interactive strategy. Harvard Business Review. 71 (4), 65-77.

Pfeffer J. (1994). Competitive advantage through people Boston, MA: Harvard Business School Press.

Pfeffer, J. \& Salancik, G. (1978). The external control of organizations. New York: Harper \& Row.

Planning Review. (1994). How to identify and enhance core competencies. 22(6), November-December, 24-26.

Powell, W.W. (1990). Neither market nor hierarchy, network forms of organizations. Research in Organization Behavior, 12, 295-336.

PR Newswire Europe. (2002) Reuters. September 20.

Prahalad, C. \& Hamel, G. (1990). The core competencies of corporations. Harvard Business Review, 30, 25-42.

Ramanathan, K., Seth, A. \& Thomas, H. (1997). Explaining joint ventures, alternative theoretical perspectives. In P. W. Beamish and J. P. Killing (eds.), Cooperative strategies, Vol. 1. North American perspectives (pp. 51-85). San Francisco, California: New Lexington Press.

Reicheld, F. (1996). The loyalty effect. Cambridge, MA: Harvard Business School Press. 
Reynolds, A. (1984). Current valuation techniques. Accounting Review. 52(2), 183-198.

Ring, P. \& Van de Ven, A. (1992). Structuring cooperative relationships between organizations. Strategic Management Journal, 13, 483-98.

Ring, P. \& Van de Ven, A. (1994). Developmental processes of cooperative interorganizational relationships. Academy of Management Review, 19(1), 90-118.

Scanzoni (1979). Social exchange and behavioral interdependence. In R. Burgess and T. Houston (eds.) Social exchange in developing relationships. New York: Academy Press.

Shocker, A.D., Srivastava, R.K. \& Ruekert, R.W. (1994). Challenges and opportunities facing brand management, an introduction to the special issue. Journal of Marketing Research, 31, 149-158.

Slater, S. \& Narver, J. L. (1995). Market orientation and the learning organization. Journal of Marketing, 59(5), 63-74.

Slater, S. \& Narver, J. L. (1999). Market oriented is more than being customer-led. Strategic Management Journal, 20, 165-168.

Srivastava, R.K., Tassadua, A.S. \& Fahey, L. (1998). Market-based assets and shareholder value, a framework for analysis. Journal of Marketing, 62, 2-18.

Thompson, J. (1967). Organizations in action. New York: McGraw-Hill Book Company.

Thorelli, H. (1986). Networks, between markets and hierarchies. Strategic Management Journal, 7 (Nov), 37-51.

Valentino, D. (1992). Do more of what you do best. Across the Board, 29(II), November, $53-54$.

Von Hayek, F. A. (1960) The constitution of liberty. London: Henley.

Von Hippel, E. (1978). A customer active paradigm with evidence and implications. Journal of Marketing, 42(Jun), 39-49.

Walker, G., Kogut, B. \& Shan, W. (1997). Social capital, structural holes and the formation of an industry network. Organization Science, 8, 109-125.

Webster, F. (1992). The changing role of marketing in the corporation. Journal of Marketing, 56(4), 1-17.

Weedman, J. (1992). Informal and formal channels in boundary spanning communication. Journal of the American Society for Information Service. 43(3), 257-267. 
Wernerfelt, B. (1984). A resource-based view of the firm. Strategic Management Journal, 5, $171-180$.

Willens, R. (1993). Amortization of intangibles, Is a mergers and acquisitions boom imminent? The CPA Journal, 63(11), 46-57.

Williams, J., Han, S., \& Qualls, W. (1998). A conceptual model and study of cross-cultural business relationships. Journal of Business Research, 42, 135-43.

Williamson, O.E. (1975). Markets and hierarchies, analysis and antitrust implications. New York: Free Press.

Williamson, O. E. (1985). The economic institutions of capitalism. New York: The Free Press.

Yamagishi, T., Gillmore, M. R. \& Cook, K. S. (1988). Network connections and the distribution of power in exchange networks. The American Journal of Sociology, $\underline{93}(4), 833-852$.

Yi, Y. (1990). A critical review of customer satisfaction. In V. Zeithaml (Ed.) Review of marketing. Chicago: American Marketing Association, 68-123.

Zellner, W. Schmidt, K., Ihlwan, M. \& Dawley, H. (2001). How well does Wal-Mart travel? After early missteps, the retailing giant may finally be getting the hang of selling overseas. Business Week, September 3, 82- 92.

Timothy S. Kiessling is an Assistant Professor of Management at Eastern Kentucky University. He has published in academic journals such as Thunderbird International Review, Journal of Global Marketing, Journal of Applied Management and Entrepreneurship, International Journal of Human Resource Management, and International Journal of Intercultural Relations. Professor Kiessling has over 14 years in international business before entering academia.

R. Glenn Richey is an Assistant Professor of Supply Chain Management at The University of Alabama. He has published in academic journals including American Business Review, International Journal of Logistics Management, International Journal of Physical Distribution \& Logistics Management, Journal of Business Logistics, Journal of International Management, and Journal of Marketing Channels. Before joining academia, professor Richey worked for 10 years in various supply chain management positions. 